\title{
The word Aborigine (Given by the Latin Word Aborigine ,from the Beginning“) Generally Means Indigenous People.
}

\author{
Nathalie Ortner ${ }^{1}$, \\ Bachelor Degree of Architecture Study Program \\ Hochschule Ostwestfalen- Lippe \\ Germany \\ nathalie.ortner@web.de
}

\begin{abstract}
We hope you win your battle... we know what it's like to fight for your rights." - Carol Barker, Aborigine (2000). By dreams we mean the belief that these beings long ago started human society - they made all natural things and put them in a special place. These dreaming beings were connected with special places or ways and paths." - Aborigine man (2014). We're still living in pain and trauma." - Yalmay Yunupingu, Aborigine (2014). If we lose this bond to the country, there will be nothing left. We will be wiped out. We exist as a people through our ancestral land. That is all we are." - Adrian Burragubba, Aborigine (2015).
\end{abstract}

Index Terms - Aborigine, Latin, word.

going to spend some time in Australia.

\section{INTRODUCTION}

The word Aborigine (given by the Latin word ab origine „from the beginning“") generally means indigenous people.

In the following I will be responding to their culture, art and lifestyle, how those have changed over time and what their life looks like today. As well I will deal with their current problems they are confronted with in the Australian society and what the government is doing about it. Furthermore I want to introduce a true story that has impressed me very much during my research. It is about a woman who was taken from her family and tribe at an early age, to be raised by white men[1].

I chose this topic not only because of my interest in Aboriginal life, but also because I am generally interested in Australia, the way of life there and the changes that have taken place over time. After my stay in Indonesia I am

\section{RESULT AND ANALISYS}

\section{A. Purpose of Life}

The Aborigines, who have a highly connection to nature, are convinced that the country with all its treasures doesn't belong to mankind. For them it is exactly the other way round. Birth, life and death are part of an eternal cycle that is impenetrably renewed by the power of spirit. This circulation always begins with the spirit and finally returns to the spirit.

The Aborigines describe the earth as a sacred breeding ground and source of life. Therefore their aim is to live in harmony with nature and not to destroy it. Dreamtime is an important term from the mythology of the natives. It describes the process of creation as a perpetual and constantly renewing process. The events of the Dreamtime are shown, according to their faith, in landmarks such as rocks, springs and other natural phenomena. Neither money 
nor property is a privilege in their society.

\section{B. Early Colonization}

The indigenous Australians have expanded their culture for 60.000 years. Some archeologist say it was 48.000 years ago. But that's still controversial today. Until the 19th century they lived as Stone Age hunters and gatherers. By burning bushes they promoted the growing of plants which were the favourite food of their wild game. They also were experts in finding water sources. They neither developed the writing nor the farming, tools made of metal as well as bow and arrow were unknown to them.

Historians and archaeologists assume that the Aboriginal ancestors left their native country, which could have been Indonesia and made their way by travelling from island to island, finally reaching the continent of Australia. Whether the crossing was deliberate or fortuity or if they could have seen the continent by distance - maybe some huge bushfires - it can only be speculated upon. Even though they had rarely knowledge of boating and shipping they finally managed to reach the continent of Australia. As the sea levels were much lower than they are today, it was probably possible to reach their destination with rafts made of bamboo or mangrove. The Aborigines brought a large part of their knowledge and customs to the „New World“".

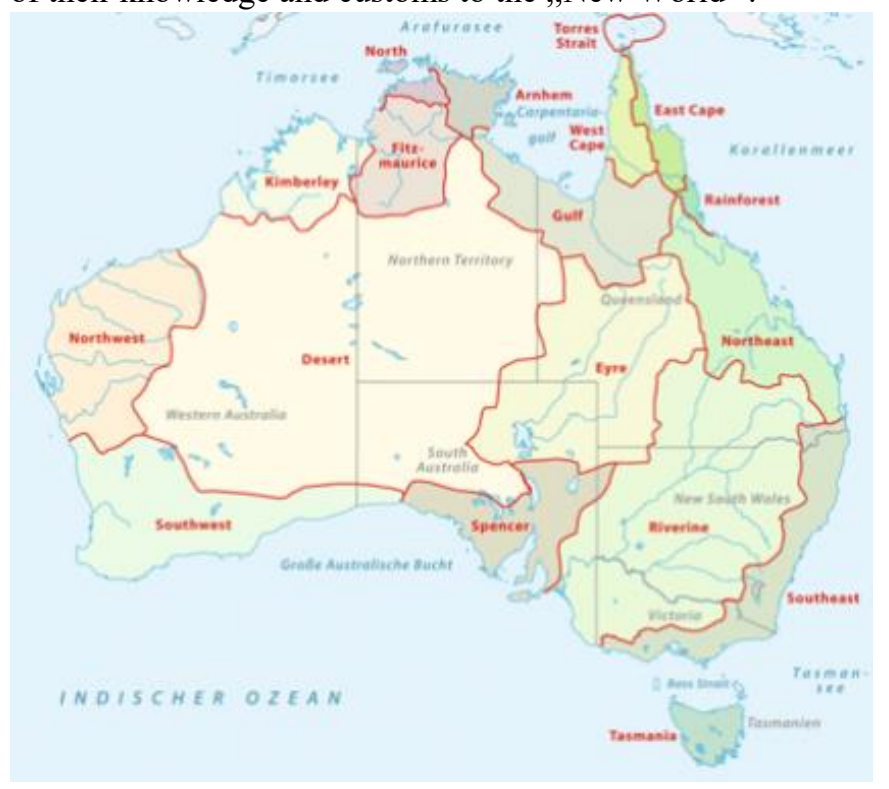

Fig. 1. Map of Australia

Several hundred tribes existed, but there were no hierarchical societies. The family was the most important pillar in the life of an Aborigine and it still is. The natives lived as nomads, in clans of 25 to 50 people. They roamed their tribal areas, obtained food by hunting and gathering, at the coasts as well by fishing. The roles were usually classically distributed. As a consequence women collected fruit and plants and men went hunting. They used spears and boomerangs which were very simple but fulfilled their purpose. Private property didn't exist, everything was shared.
Indigenous Australians (Aboriginal Australians and Torres Strait Islanders)

\begin{tabular}{|c|c|}
\hline \multicolumn{2}{|c|}{ Total population } \\
\hline \multicolumn{2}{|c|}{$\begin{array}{c}798,365(2016)^{[1]} \\
\text { 3.3\% of Australia's population }\end{array}$} \\
\hline \multicolumn{2}{|c|}{ Population distribution by state/territory } \\
\hline New South Wales & $265,685 \quad(3.55 \%)$ \\
\hline Queensland & $221,276 \quad(4.57 \%)$ \\
\hline 응 Western Australia & $100,512 \quad(3.93 \%)$ \\
\hline o Northern Territory & $74,546(30.34 \%)$ \\
\hline Victoria & $57,767 \quad(0.94 \%)$ \\
\hline South Australia & $42,265 \quad(2.47 \%)$ \\
\hline masmania & $28,537 \quad(5.51 \%)$ \\
\hline $\begin{array}{l}\text { A Australian Capital } \\
\text { Territory }\end{array}$ & $7,513 \quad(1.86 \%)$ \\
\hline \multicolumn{2}{|c|}{ Languages } \\
\hline \multicolumn{2}{|c|}{$\begin{array}{l}\text { Several hundred Indigenous Australian } \\
\text { languages (many extinct or nearly so), } \\
\text { Australian English, Australian Aboriginal } \\
\text { English, Torres Strait Creole, Kriol }\end{array}$} \\
\hline \multicolumn{2}{|c|}{ Religion } \\
\hline $\begin{array}{r}\text { Christiar } \\
\text { Non-religi } \\
\text { Traditional Abori }\end{array}$ & $\begin{array}{l}73 \% \\
24 \% \\
\text { aligion } 1 \%\end{array}$ \\
\hline \multicolumn{2}{|c|}{ Related ethnic groups } \\
\hline Papuans, $\mathrm{N}$ & nesians \\
\hline
\end{tabular}

Fig. 2 The population of Indigenous Australiens [2], https://de.wikipedia.org/wiki/Aborigines

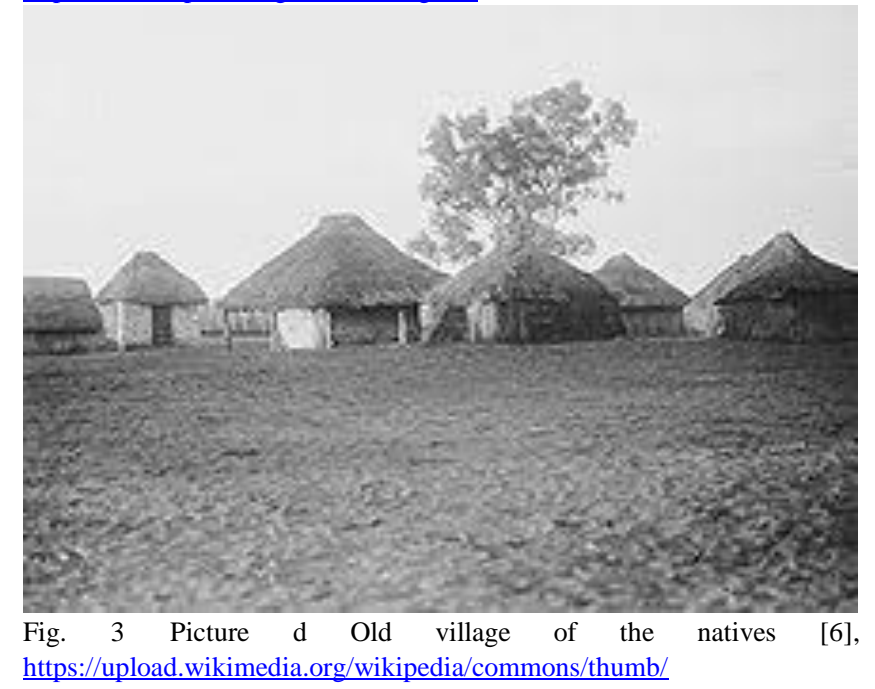




\section{European Settlers}

At the end oft he 18th century white men settled the continent and everything changed. The settlers stole their land, the Aborigines were slaughtered and their traditions were disregarded. As they were treated very badly it looked like they were going to be wiped out.

The first people discovering Australia were the Europeans in 1606. However the fateful day for the Australian natives was January 26, 1788, when an English fleet leaded by Captain Arthur Phillip landed at the southeast coast of the continent, the later Sydney. At this time the prisons in England were overcrowded and the British crown decided to send the occupants to the other end of the world, to get rid of them. So almost every passenger was a criminal. During the following 80 years over 800 ships with prisoners arrived and more than 160.000 deportees tried to start a new life in Australia. In order to defuse the conflicts between the prisoners and the indigenous people, the government assigned protectorates to the Aborigines, in which they should build up settlements and practise agriculture like the white men. During this time the term „Aborigines“", which roots are found in the Latin Language: „ab origine“, established. The natives had been there ,from the very beginning“" In the linguistic usage outside Australia all natives of the fifth continent are called Aborigines, while in Australia itself it differentiates. The colonization of the Australian continent had serious consequences for the indigenous people. Nature and land had a great spiritual significance for them and provided them with water and food. Their culture was strongly affected by the expulsion from their homeland. The settlement policy also caused great suffering by splitting family groups. Many Aborigines died fighting for the territories but there were also lots of deseases brought in by the immigrants, due to which far more native people died. There was influenza epidemics and a terrible pox epidemic in 1789 in which tousands of Aborigines died. According to statistics the population of indegeous people decreased from one million to only 60.000 until 1920 . Due to the increasing prevalence of venereal diseases, sterility among women rose. Thus their social structure was destroyed, which was built on large families. Much of their culture and many traditions got lost.

\section{Arts and Culture}

The earliest forms of Australian art are engravings and paintings were found in rock heights, some of which are about 40.000 years old. It is the oldest art tradition in the world that still exists today. Creation myths were placed in caves and the Aboriginal ancestors once painted their shields and spears with them.

Another early art form is the bark painting, which was often used for ceremonial purposes. This technic uses the interior of a strip of a tree bank which is beeing painted.

The artist is always the owner and participant of the content which is presented. It is only for his specific purpose and he has the right to use sacred patterns to depict the religious content. It would be a serious violation of a traditional unwritten law, to use a design which is owned by somebody else without the permission of the one.

, In Aboriginal art, whether traditional or modern, there are two levels of interpretation: The ,inner" stories intended only for those who have the appropiate ritual knowledge, and the ,outer" stories accessible to all..."

Today the art of the indigenous people can be found all over Australia. Native artists produce vivid paintings in various styles. They design sculptures of native grasses, wool and strings as well as prints, glassware, hand-printed fabrics and jewellery. All kinds of art can be purchased in galleries for a thousand dollars as well as at souvenir stalls for little money.

For strangers the art objects are above all colourful and decorative, but each of them tells its own story. The time of the colonization and the creation of the country has been passed down orally in various myths. It can also be traced in by the countless rock paintings which seam to be natural ,libraries"،

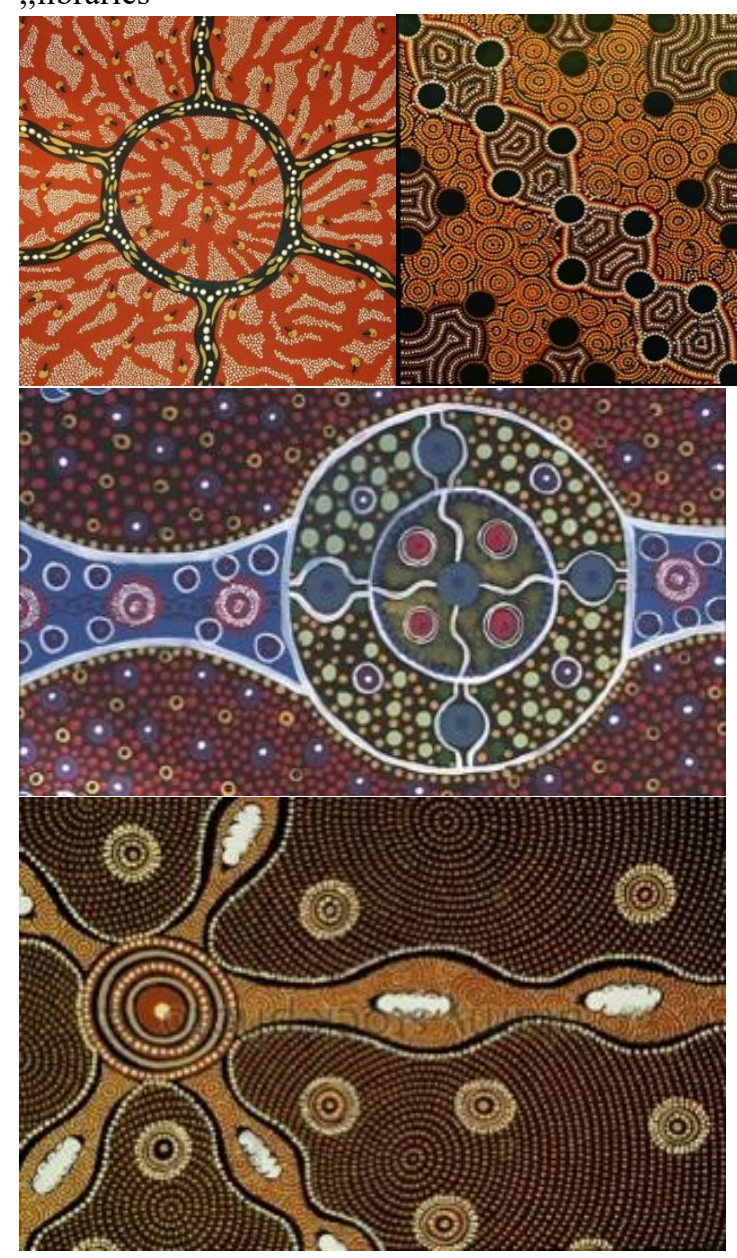

Fig. 4. Picture e The ancient art of the natives, https://www.pinterest.com/pin/493073859188303046/

\section{E. The Stolen Generation}

In 1910 the government and the church started a particularly brutal attempt at assimilation. In the course of 
this thousands of children, especially those of mixed race origin, were seperated from their parents. This ,stolen generation" was forcibly placed with foster families or in mission stations. The government explained that this measure was for adapting them to he ,white way of life ", to assimilate the lighter-skinned offspring for a life in ,,white" Australia. In truth the measure was intended to eradicate the language and the culture of the Aboriginal people. For their roles in the forced adoptions the churches, the govenor general and, as representative of the Australian head of State, Queen Elizabeth II apologized.

May O'Brien belongs to this „Stolen Generation“. As an Aborigine she was forcibly adopted by whites. Her life was full of disruptions and changes. She survived this terrible time, found her love for language and literature and uses her experiences to write childrens' books.

She was born in Laverton, Western Australia - the Outback under the poorest conditions. Up to the age of five she grew up among white missionary sisters at the Mount Margaret Aboriginal Mission, according to western ideas. After 12 years she went to the University of Perth as one of very few indigenous students. She became the first female Aboriginl teacher in Western Australia. After teaching 25 years at Mount Margaret Primary School she decided to start a career in school administration. She became head oft he government's Aboriginal Education Branch and was responsible for the educational efforts towards the indigenous population.

In December 1977 May O'Brien was awarded the British Empire Medal for her work in Aboriginal education. For her commitment she was also got the John Curtis Medal. In 1980 at the United Nations Conference on Women in Denmark she was a delegate for Australia.

As writing is her passion she is also the author of lots of childrens' books, which reflect the traditional life in the Outback as she herself experienced it. The books are intended to explain nature and its habits to children, to bring them closer to the theme of nature again. Her childhood experiences habe been incorporated into her work, says May O'Brien. Her childrens' books have made her famous in Australia. The stories have always a clear moral - like fables. In addition she wrote books which can be used as teaching material at schools. Further her treatises on indegenous topics such as assimilation, racism, feminism and Aboriginal history found great interest.

Once she charged the white people: ,, The whites thought we were the dust of the earth. They looked down on us like dogs. " She didn't want to be dust, she wanted to change the situation - a unique career in Australia.

\section{F. Current Situation}

Nowadays the situation of Australia's indigenous people has unfortunately not improved. They were forced to move to communities founded for them. Most of this places were built far from those of European immigrants. The families affected, were initially unaware of the background of the forced settlement. Education for their children, safe accomodation and better care - all this seemed to be attractive to them. The consequences only became visible later: alienation and uprooting. As symptons of the discrimination against the Aborigines, experts refer to many self-inflicted injuries and the high suicide rate. They are less likely to graduate from school, they are affected more than average by alcohol and drug abuse and live on average ten years less than the rest of the population.

Almost a third of Aborigines suffer from severe psychological problems. Self injuries have increased by 56 percent during the last 15 years, detentions by 77 percent. The suicide rate, among male Aborigines between 25 and 29 years of age, ist he highest in the world. Only recently, reports of a suicide wave with up to 19 cases within three months in the Northwest of Australia had rocked the country, the latest victim being a ten-year-old girl.

But not only psychological problems led to the low life support of the people. At the beginning of the 1970s, when the natives became legal access to alcohol, the crash was inevitable for many of them. They had not learned how to use the drug because alcohol did not occur in their traditional lives. Aborigines have a significantly higher proportion of uncontrolled abuse, although they consume less alcohol per capita than the entire Australian population. Due to a report, every 38 hours one Australian Aborigine is dying from drinking alcohol.

To families the damage caused by alcohol is very serious. In particular women and children suffer from physical violence and sexual abuse.

This problem started when many unemployed indigenous people moved to the cities in desperate search of work. Living in urban residential areas their lives changed completely.

The best-known district with enormous problems is Redfern, which is situated close tot he city centre of Sydney. The district is known as „The Block“. In 1973 the goverment bought the land and handed it over to an Aboriginal housing company which was set up specifically for this purpose. The Block was conceived with 21 houses as social housing and at first was celebrated as a symbolic victory in the struggle for more land rights. From about 1985 there were only bad headlines about this district. Drug abuse, unemployment, juvenile delinquency and violence were the order oft he day. Often paired with deeply felt devolution and lack of prospects it leaded to conflicts between the Aboriginal people and the police almost every day. The inhabitants often accused the officials of racism and Redfern is probably the most negative example of a settlement of urbanized Aboriginal People. As it has been built near the famous opera house, populist would prefer to tear it all down - they fear for the cityscape.

\section{G. Government Measures}

Due to the increasing problems the government was forced to act quickly and in June 2007 it declared a national 
emergency. Following measures were ordered:

- ban on alcohol and pornography in Aboriginal comunities

- compulsory medical examinations of children

- deployment of more teachers

- reinforcement of the police

- conversion of part of social assistance into food vouchers

The military supported the implementation of these measures. Lots of international reports and increasing discussions in the media were the result of the government's intervention. Among the population the measures were discussed highly controversial, many critical voices were raised. Human rights organizations described the intervention as racist and complained that the Aborigines had lost their self-determination through the use of „managers"posted in the communities by the government.

With extensive programmes Australia has been trying for years to break through this circle. One of these initiatives is „Close the Gap“". More than 30 billion dollars were spent on indigenous people and projects tailored for them, but with little success to date. The reason for this ist hat the really needs oft he individual communities are not asked for. Instead the opinion of the government is implemented, even though hardly any of the communities have been visited by government employees to discuss the real problems, critics say.

\section{H. Positive Approaches}

In every other respect the situation of the Aborigines is tried to improve. Art, music and culture but also tourism and economy make more friends with the indigenous people again.

According to one activist, there is only one promising future: ,We must build our churches from the ground up, with jobs, greater cohesion and pride in our own identidy. "“

For example, the Injalak Art Centre, a non-profit organization run by Aborigines. The centre in Northern Australia sells indigenous art and offers visits to historic stone paintings in nearby caves. In this way jobs are created and maintained, the profits are invested in the community.

With various ambitious tourism projects Aboriginal people generate hundreds of millions of dollars in international income every year. In the meantime they also benefit from tourism. Their sacred sites, such as the Uluru (Ayers Rock) or the Kakadu National Park are visited by thousands of tourists yearly. Other important areas are the Tiwi Islands, the Kings Canyon, Katherine and Cape Tribulation. At these places a very close connection to the indegenous people can be found.

Another possibility is the private economy. In Lockhart River at the Northern tip of Australia, partnerships between private indigenous entrepreneurs and the local community are a success. Aboriginal startups provide services such as garden- or street maintenance and caterings.

By searching for mineral resources, the Pilbara region oft he Hamersley Range is a great role model. Since the end oft he 1980s competence and performance have counted at this mining. Skin colour and origin have never mattered. At this iron ore mine Aboriginal people are fully accepted and also work in high positions.

The long-lasting art of the Aborigines is still a gain for the world of art, the paintings and drawings of them have long since become a hit in galleries around the world and are sought-after and valuable collectors' items. The patterns also appear on fabrics and garments. Prehistoric art has grown far beyond the stage of mere fashion.

Young artists have recently broken free from isolation and have achieved astonishing success in the art and culture world. Dance- and music groups, writers and painters make themselves messengers of the Aboriginals. The popular rock group YOTHU YINDI stood up with their hit Treaty. They demand a self-determination contract and provide worldwide publicity. All this artists want the Austalians“ consciousness to change.

Trying to induct a change, they have found a little pride. Some are trying to live in the traditional way again - but that is of course almost impossible, because civilization is also progressing in the endless red desert of Australia.

As sign of their return to their origins and also for their new self-confidence they got their own flag. Its ' colours black, red and yellow have an important meaning for the Aboriginal flag. The colour red represents Mother Earth. The ochre collected in Ochre Pits near Alice Springs for example is often used for ceremonial acts. Yellow stands for the sun, the constant giver and innovator of life. Black means the Dreamtime in which everything came into being. Together the three colours symbolize the basics of Aboriginal life.

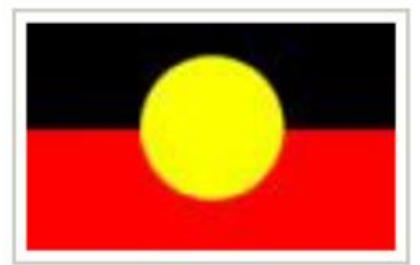

Fig. 4. Picture f Three colours of the Aboriginal life, https://upload.wikimedia.org/wikipedia/de/thumb/7/77/Flag_of_the_Austr alian_Aborigines.svg/1200px-

\section{CONCLUSION}

I first discovered my interest in the Aborigines when I visited high school. During the German lessons we read the book Follow The Rabbit-Proof Fence by Doris Pilkington. The true life story of the girl Molly and her two younger cousins who are taken over a thousand miles away from their families was really hard to read. The children were treated badly, they were not even allowed to speak their own language. Anyone who tried to escape was brought back and beaten. They ran away however and managed to make a long trek home again. Later there was also a film about the theme which was first told in the book of the same 
name by Molly's daughter Doris Pilkington.

This was my first contact with part of the history of Australia. I was shocked but also impressed by the perseverance of these children. Later I read more about the indigenous people and their way of life. It makes me sad to read about all the suffer, I think it is very difficult for Europeans to understand their dealing with things. But if non Australians can support the Aborigines it is by making donations for organizations which support the Aboriginal way of life.

I'm also interested in their kind of art which is completely different from ours. I look forward to visiting all the cultural sites with the phantastic gravings and paintings.

To work on the presentation of the indigenous population from different perspectives turned out to be challenging, but quite enlightening. It remains to be seen, however, how this topic will further develop, as the latest political and social trends in Australia may well lead to changes in the way of living.

The Dreamtime of these very special people is best remembered by themselves, but the culture of the Australian natives is still based on the memory of the origin of life of all other people in the world.

\section{REFERENCES}

[1] Gerhard Leitner, "Die Aborigines Australiens" 1998. 